\title{
The Measurement of the Placenta, Umbilical Cord and Components of Amniotic Fluid in Beagle Dogs
}

\author{
Satoshi FUKUDA and Osamu MATSUOKA \\ Division of Radiation Hazards, National Institute of Radiological Sciences, 4-9-1, Anagawa, \\ Chiba, 260, Japan
}

(Received for publication January 13, 1978)

\begin{abstract}
The body weight of newborns, the weight of placenta, the length of umbilical cord and the content of urobilinogen, gulcose, protein, $\mathrm{pH}$, keton body in amniotic fluid were investigated with samples from 16 litters of beagles. The mean body weight of newborn, weight of placenta and length of umbilical cord were $258.0 \pm 44.6 \mathrm{~g}$ (85 samples), $48.5 \pm 8.5 \mathrm{~g}$ (85 samples) and $11.0 \pm 2.7 \mathrm{~cm}$ (52 samples), respectively without any sex difference. The significant correlation were recognized between the weight of placenta and the body weight of newborn, between the length of umbilical cord and the body weight of newborn and between the weight of placenta and the length of umbilical cord $(P<0.01)$.
\end{abstract}

\section{ビーグル犬の胎盤重量, 臍帯長および}

羊水の性状, 成分について

福田俊・松岡 理

放射線医学総合研究所障害基礎研究部

実験用ビーグル犬の胎盤重量, 臍带長および羊水の性 状, 成分の測定結果の報告例は少ない。その理由として 一般に犬の分姢は深夜から早朝にみられること, 分姢後 ただちに母犬が胎盤を食することなどが考文られる。

そこで本報ではビーグル犬の繁殖学的基礎データを得 る目的で生下時の体重, 胎盤重量, 臍帯長および羊水の 性状，成分について測定した結果を報告する。

\section{材料およひ測定方法}

実験動物はシーエスケー実験動物研究所由来のビーグ ル犬を主に兄妹交配，一部もどし交配によって放医研で 自家生産した動物を使用した。飼育は温度 $20 \sim 24^{\circ} \mathrm{C}$,
湿度65～85\%の環境下で行なわれている。ただし，晴天 時には 1 日 1 回約 2 時間程度屋外で運動させている。飼 料は日本クレア (株) の犬用固型飼料C D-5を 1 日 2 回 $100 \mathrm{~g}$ ずつ与えている。妊娠犬には分婏予定日の 7 10 日前頃から, 飼料を 1.5〜 2 倍量に増加するとともに市 販の乳児用粉末ミルクを加えて食欲増進を計っている。

実験の対象とした母犬は $1 \sim 4$ 才の雃13頭で, 交配は 胵垢の細胞像, 陰部の腫腿状態から判断し, 自然交配を 出血開始後10〜12日目に 1 回だけ行なった動物である。 今回の測定に用いた材料はこのようにして妊娠させた13 頭の16産から得たものである。この16産の妊娠期間（交 配日から出産日までの日数）は平均 $60.8 \pm 1.6$ 日であ った。 
Table 1. Components of Amniotic Fluid

\begin{tabular}{|c|c|c|c|c|c|c|}
\hline & \multicolumn{2}{|r|}{ Male } & \multicolumn{2}{|c|}{ Female } & \multicolumn{2}{|r|}{ Total } \\
\hline & No. & propotion & No. & propotion & No. & propotion \\
\hline \multirow{2}{*}{\multicolumn{7}{|c|}{$\begin{array}{l}\text { Urobilinogen } \\
\text { (Ehrlich unit } / 100 \mathrm{ml})\end{array}$}} \\
\hline & & & & & & \\
\hline 0.1 & 9 & $37.5 \%$ & 10 & $31.2 \%$ & 19 & 33.9 \\
\hline 1 & 6 & 25.0 & 7 & 12.9 & 13 & 23.2 \\
\hline 4 & 5 & 20.8 & 7 & 21.9 & 12 & 21.4 \\
\hline 8 & 4 & 16.7 & 7 & 21.9 & 11 & 19.7 \\
\hline \multirow[t]{2}{*}{12} & 0 & 0 & 1 & 3.1 & 1 & 1.8 \\
\hline & 24 & 100.0 & 32 & 100.0 & 56 & 100.0 \\
\hline \multicolumn{7}{|c|}{ Glucose $(\mathrm{mg} / 100 \mathrm{ml})$} \\
\hline 0 & 4 & $15.4 \%$ & 6 & $19.4 \%$ & 10 & $17.5 \%$ \\
\hline$<250$ & 1 & 3.8 & 5 & 16.1 & 6 & 10.5 \\
\hline $250-500$ & 7 & 26.9 & 12 & 38.7 & 19 & 33.3 \\
\hline \multirow[t]{2}{*}{$500<$} & 14 & 53.9 & 8 & 25.8 & 22 & 38.7 \\
\hline & 26 & 100.0 & 31 & 100.0 & 57 & 100.0 \\
\hline \multicolumn{7}{|c|}{ Protein $(\mathrm{mg} / 100 \mathrm{ml})$} \\
\hline trace & 1 & $3.7 \%$ & 1 & $2.9 \%$ & 2 & $3.3 \%$ \\
\hline 30 & 1 & 3.7 & 3 & 8.8 & 4 & 6.6 \\
\hline 100 & 21 & 77.8 & 21 & 61.8 & 42 & 68.9 \\
\hline 300 & 3 & 11.1 & 9 & 26.5 & 12 & 19.7 \\
\hline \multirow[t]{2}{*}{1000} & 1 & 3.7 & 0 & 0 & 1 & 1.5 \\
\hline & 27 & 100.0 & 34 & 100.0 & 61 & 100.0 \\
\hline \multicolumn{7}{|l|}{$\mathrm{pH}$} \\
\hline 6 & 5 & $17.9 \%$ & 5 & $15.2 \%$ & 9 & $14.8 \%$ \\
\hline 7 & 13 & 46.4 & 12 & 36.4 & 26 & 42.6 \\
\hline \multirow[t]{2}{*}{8} & 10 & 35.7 & 16 & 48.4 & 26 & 42.6 \\
\hline & 28 & 100.0 & 33 & 100.0 & 61 & 100.0 \\
\hline \multicolumn{7}{|l|}{ Quantity } \\
\hline$(\mathrm{ml}, \mathrm{M} \pm \mathrm{SD})$ & 3 & $222.7 \pm 59.2$ & 4 & $262.8 \pm 82.8$ & 7 & $245.6 \pm 71.1$ \\
\hline
\end{tabular}

各測定項目の例数は測定が可能であった胎盤85例, 臍 帯52例そして羊水の61例である。ただし, 羊水の性状, 成分において一部の項目について測定不可能な例が若干 あった。また羊水量は帝王切開を行なった 1 産の 7 例で 計量が可能であった。材料の採取および測定の手順は次 のように行なった。まず, 胎仔の婏出と同時に胎盤を摘 出し, 羊水をビーカ一内に採取した。そして脆带を結紮 し仔犬を片手で保定後, 胎盤を宙吊にした状態で仔犬の 臍輪から胎盤に最も近い部分までを臍带長として $5 \mathrm{~mm}$ 精度で測定した。続いて臍帯を臍輪から約 $5 \mathrm{~mm}$ の位置
で切断し，臍帯とともにペーパータオルで水分を充分に 除きこれを胎盤重量として測定した。最後に，羊水中の ウロビリーノゲン, グルコース, 蛋白, $\mathrm{pH}$ およびケト ン体の性状および成分の測定を試験紙（市販名：ウロラ ブスティック）によって行なった。

\section{成 縤}

仔犬の生下時の体重, 胎盤重量および腯带長の測定結 果を Fig. 1 に, 羊水の性状および成分の 測定結果を 

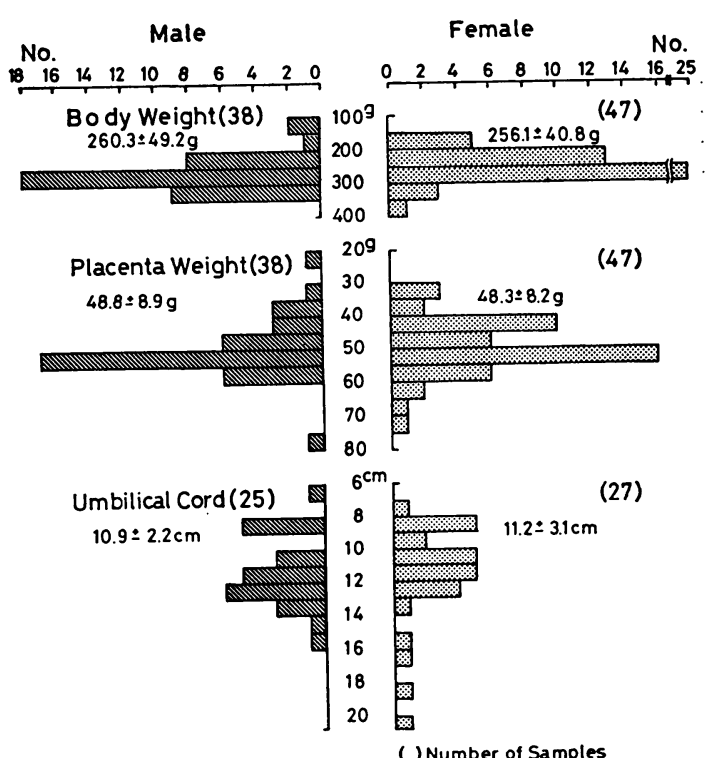

Fig. 1. Distribution of Body Weight, Placenta Weight and Umbilical Cord Length on Male and Female

Table 1 にそれぞれ䧳雄別に示した。仔犬の生下時の 体重の平均は雄 $260.3 \pm 49.2 \mathrm{~g}$, 雌 $256.1 \pm 40.8 \mathrm{~g}$, 全 体では $258.0 \pm 44.6 \mathrm{~g}$ (85例) であった。胎盤重量は雄 $48.8 \pm 8.9 \mathrm{~g}$ ，雌 $48.3 \pm 8.2 \mathrm{~g}$ ，全体では $48.5 \pm 8.5$ $\mathrm{g}$ (85例) であった。臍帯長は雄 $10.9 \pm 2.2 \mathrm{~cm}$, 雌 11.2 $\pm 3.1 \mathrm{~cm}$ ，全体では $11.0 \pm 2.7 \mathrm{~cm}$ (52例) であった。以 上のように, 生下時の体重, 胎盤重量, 臍带長および羊 水の性状，成分のそれぞれについて雌雄間に差違は認め られなかった。したがって以下の分析は雌雄を合わせて 行なった。

生下時の体重は 250 299 g を示した例が 約 50\%（85 例中43例）あった。胎盤重量は50〜 $54 \mathrm{~g}$ の範囲を示した 例が最も多く（85例中 34例），40〜 $59 \mathrm{~g}$ の範囲を示した 例は70例で全体の $82.4 \%$ あっあた。臍帯長は8.0 8.4cm （10例）と $10.0 \sim 12.9 \mathrm{~cm}$ (28例) を示した例が最も多く みられた。羊水の性状および成分の測定結果, ウロビリ ノーゲンは Table 1 に示したよらに $98.2 \%$ (56例中55 例）が $0.1 \sim 8$ Ehrlich unit $/ 100 \mathrm{ml}$ の範囲を示した。 グルコースは250〜 $500 \mathrm{mg} / 100 \mathrm{~m} \ell$ の範囲または $500 \mathrm{mg} / 100$ $\mathrm{m} \ell$ 以上を示すものが72\%あった。蛋白はほとんどが 100 $\mathrm{mg} / 100 \mathrm{~m} \ell$ 示した（61例中42例）。 $\mathrm{pH}$ はほとんどが $\mathrm{pH}$ 7 または $\mathrm{pH} 8$ を示した。ケトン体はまったく検出さ れなかった。羊水の量は平均 $245.6 \pm 71.1 \mathrm{~m} \ell(7$ 例) で
あった。

次に仔犬の生下時の体量と胎盤重量ならびに臍带長と の，また，胎盤重量と臍帯長とのそれぞれの関係を検討 し Fig. 2〜 4 に示した。胎盤重量と生下時の体重は回 帰式 $y=0.1070 x+20.9364$ （相関係数 $r=0.5624$ ) で，臍带長と体重は， $y=0.0316 x+2.7526(r=0$. 5346)，また胎盤重量と臍带長は $y=0.1952 x+1.2517$ $(r=0.5619)$ で表わされ，それぞれの関係は有意（P く0.01）であった。一方羊水の各性状扰よび成分と体重 との間には有意な関係は認められなかった。

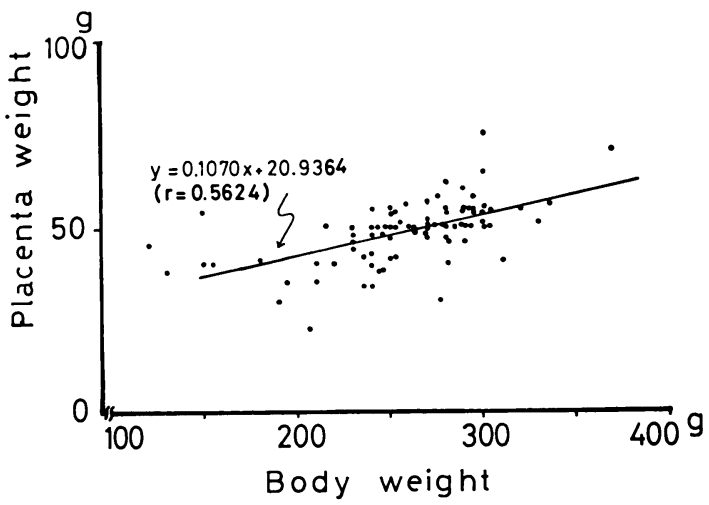

Fig. 2. Correlation between Body Weight and Placenta Weight

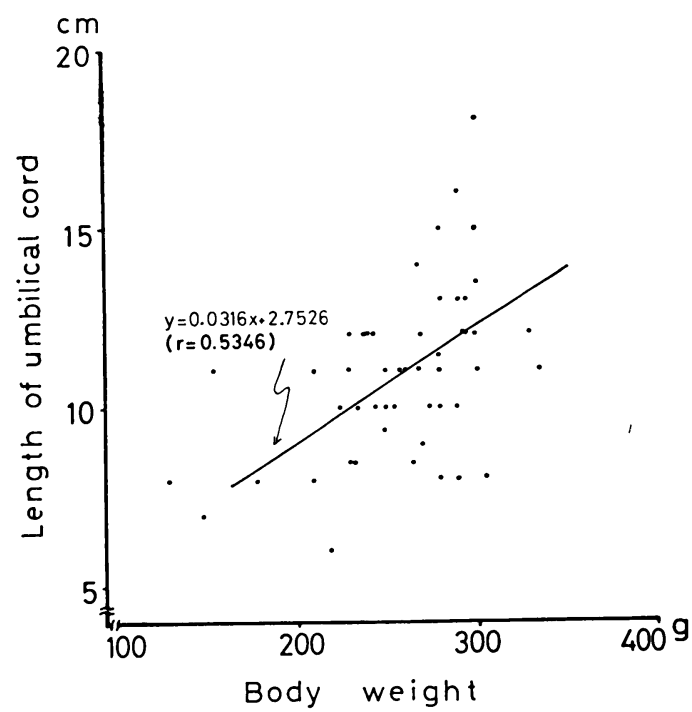

Fig. 3. Correlation between Body Weight and Length of Umbilical Cord 


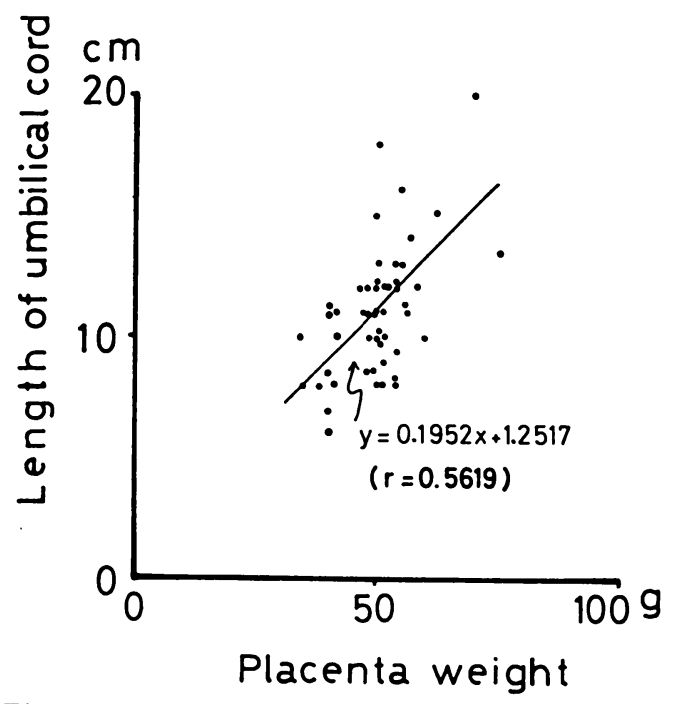

Fig. 4. Correlation between Placenta Weight and Length of Umbilical Cord

さらに Litter size と胎盤重量, 脆带長, 羊水の性状 および成分との関係を検討した。ただし，16 産のうち Litter size 4，6，10，11 はそれぞれ 1 産ずつだけであ り, 得られた例数も少ないので除外した。したがって, Litter size 7 を示した 4 産から得た 26 例, Litter size 8 の 4 産から得た 26 例, Litter size 9 の 4 産から得た 21例を対象とした。それぞれの Litter size での胎盤重 量の分布は, Litter size 7 および 8 では50〜 $54 \mathrm{~g}$ を示 したものが最も多くそれぞれ $38.5 \%$ ，46.2\%を示した。 Litter size 9 では55〜59gを示したものが多く（28.6 \%)，50５9g を示したものは 42.9\%あった。脆帯長と の検討では，各 Litter size ともに 4 産から得られた 21例，13例，12例について行なった。Litter size 7 で は8.0〜8. $9 \mathrm{~cm}$ （7例）と10.0 10.4cm（5 例）を示した ものが多くみられた。Litter size 8 では12.0 12.4cm を示したものが最も多く(13例中 6 例) みられた。Litter size 9 では 10.0〜 10.4cm, 11.0〜11.4cm を示したもの がそれぞれ 3 例ずつあった。

羊水の各性状および成分ともに Litter size による相 違は認められなかった。

最後に仔犬の生死と各測定項目との関係について検討 した。放医研では離乳を行なら 1.5〜 2 力月令までに死 亡する例の約 $70 \%$ 近くが出生後 1 週間以内にみられる。 したがって本報の内容から考えて出生後 1 週間以内に生 死したものを対象とした。生下時の体重は生存 $270.7 \pm$ $27.1 \mathrm{~g}$ ，死亡群 $249.1 \pm 51.9 \mathrm{~g}$ であった。これを倠雄別
にみると雄の生存群 $281.8 \pm 26.5 \mathrm{~g}$, 死亡群 $247.8 \pm 55$. $3 \mathrm{~g}$, 雃の生存群 $263.2 \pm 25.5 \mathrm{~g}$, 死亡群 $250.4 \pm 49.7 \mathrm{~g}$ であった。生存群と死亡群とのおよび皆または雄の生存 群と死亡群とのそれぞれの間に有意差が認められた（ $\mathrm{P}$ $<0.01)$ 。

胎盤重量については 1 週間以上生存した群と 1 週間以 内に死亡した群とに分けて Fig. 5 に示した。生存群の 平均胎盤重量は $52.1 \pm 6.0 \mathrm{~g}$ (35例)，死亡群のそれは $46.6 \pm 9.0 \mathrm{~g}$ (50例) で両者間に有意な差違が認められ た $(\mathrm{P}<0.01)$ 。また, 生存群では全例 $40 \mathrm{~g}$ 以上を示し, 50〜 $54 \mathrm{~g}$ の範囲にあったものが最も多く約 46\%を占め た。一方死亡群では生存群に比へ広範囲の分布を示し た。また死亡群では $40 \mathrm{~g}$ 以下の例が死亡群の $20 \%$ あっ た。臍帯長については11 cmをさかいに生死に多少の差が みられ，10cm以下で多くの死亡例がみられる傾向にあっ

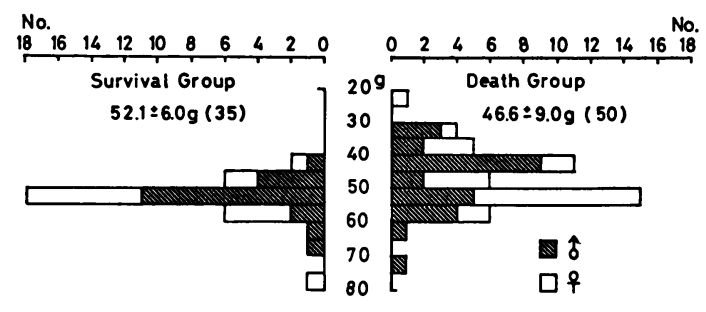

( ) Number of Samples

Fig. 5. Comparison of Placenta Weight betw. een Survival Group and Death Group

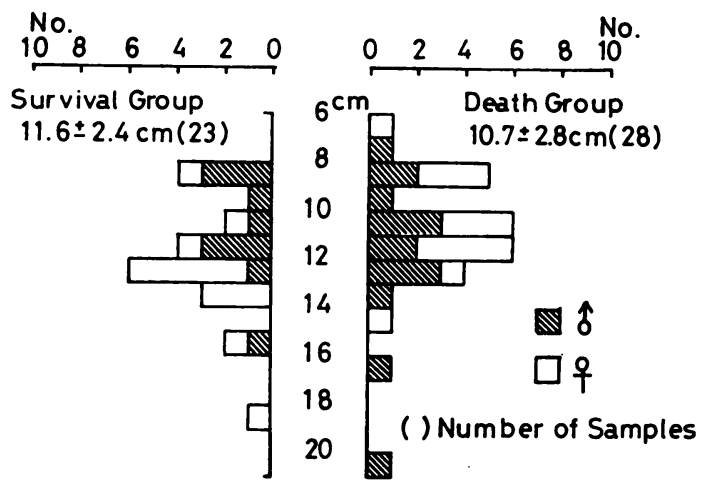

Fig. 6. Comarison of Length of Umbilical Cord between Survival Group and Death Group

た (Fig. 6)。一方，羊水の性状扰よび成分については 生存群と死亡群との間に著明な差異は認められなかっ た。Litter size 7, 8, 9 のそれぞれの生存率は $28.6 \%$, $65.6 \%, 30.6 \%$ でった。 


\section{考}

実験用ビーグル犬の繁殖学的データを得る目的で，生 下時の体重, 胎盤重量, 臍带長, 羊水の性状および成分 について測定した。

最初に各測定項目について雌雄差を検討したが，雌雄 間にほとんど差違は認められなかった。このことは子宮 内での胎仔の成長において性による差は現われないこと を示していると思われる。次に胎盤重量ならびに臍帯長 と生下時の体重, また胎盤重量と臍带長とのそれぞれの 関係について検討した。その結果，各測定項目間に有意 な相関性が認められた。このことから子宮内において胎 仔はこれに附属する胎盤，臍带とあるバランスを保ちな がら成長することが考えられる。しかし，このバランス の詳細を知るためには娭出時の 1 時点のみでなく，妊娠 期間に拈ける多時点での測定が必要である。

次に Litter size 別に各測定項目について検討した。 臍帯長において Litter size 7 に比べ Litter size 8, 9 の方が長い傾向にあると思われた。このことに関して は例数を増やして検討を加える必要があると思われた。

われわれのコロニーでは離乳時までに死亡する個体の らち約70\%が生後 1 週間以内にみられることからこの 早期死亡との関係を雌雄別, Litter size 別, 生死別に 別けることによって検討した。羊水の性状扰よび成分を 除いた各項目とも生存群と死亡群との間に差違が認めら れた。生下時の体重では福井ら [1] が観察しているよ5 に，230〜410 g の範囲の体重を示した個体は生存率が高 いよらに思われた。そこで体重と胎盤重量との関係をさ らに詳しく分析した結果，体重が $250 \mathrm{~g}$ 以下の場合体重 と胎盤との相関性が非常に低い $(r=0.2872)$ ことが知 られた。これは胎盤重量が比較的一定の值を示すのに比 ベ，体重は変動が大きいことを示している。すなわち胎 盤は十分に発育しているのに，胎仔は成長が悪いことを 示している。これらの例はとくに Litter size が大きい ときに多くみれる傾向にある。このことから， Litter size が大きくなるほど胎仔の発育は母体からの影響や
子宮内での発育環境に左右されやすくなると思われた。 とくに妊娠末期に胎仔が急激な発育 [2]をするときに影 響を受けやすいと考えられた。

以上のことから, 生下時の体重が $250 \mathrm{~g}$ 以上, 胎盤重 量が45〜 $54 \mathrm{~g}$, 臍带長が $11 \mathrm{~cm}$ 以上を示す個体は, 出生後 の生存率が高い傾向にあることから，子宮内でバランス のとれた発育をしたものであろらと考えられた。また今 回の検討からは早期死亡の原因を思わせる具体的なもの を明確にすることはできなかった。しかし胎仔の発育と 胎盤の発育との間に何らかの不調和が生じることが, 早 期死亡の原因の 1 つではないだろらかと思われた。

\section{要 旨}

ビーグル犬の生下時の体重, 胎盤重量, 臍带長, 羊水 の性状および成分の測定を繁殖学的な基礎資料を得る目 的で16産から得た85例について行なった。

1. 生下時の体重は平均 $258.0 \pm 44.6 \mathrm{~g}$ (85例), 胎 盤重量は平均 $48.5 \pm 8.5 \mathrm{~g}$ (85例), 臍带長は平 均 $11.0 \pm 2.7 \mathrm{~cm}$ (52例) であった。これらの各 測定項目拈よび羊水の性状, 成分における雌雄の 差は認められなかった。

2. 胎盤重量ならびに臍带長と生下時の体重, また胎 盤重量と渡带長との間にそれぞれ有意な相関性が 恋められた（ $\mathrm{P}<0.01 ） 。$

3. 各測定項目について新生仔の早期死亡との関係を 検討したが，具体的に原因を示すものは認められ なかった。結論として子宮内の発育期間中に, 胎 仔と胎盤ならびに臍带がバランスよく発達した時 生存しやすいことが考えられた。

\section{文献}

［1］福井正信・友田 勇・上田雄幹編 (1976). 実験用ビーグ ルの研究, ソフトサイエンス社, 東京, 43-45.

[2] Andersen, A. C. (1970). The Beagle as an experimental dog: The lowa State University Press, Ames, Iowa, S. S. A, 46-49. 